\title{
1912: Górski on Body and Self-Consciousness
}

\author{
Przemysław Nowakowski
}

Centre for Phlosophical Research, Warsaw

pnowakowski@avant.edu.pl

\section{Who is Jan Górski?}

Over a year ago, entirely by accident I came across a book by Jan Górski, Świadomość jaźni [Self-consciousness]. For a few years I had been interested in studies on self-consciousness and bodily awareness, including Polish research. Therefore, discovering this book, which deals with issues that are of interest to me, came as quite a great surprise. A quick browse through the book revealed that it is a fascinating work due not only to the topic and conclusions but also to the literature on which the author based his analysis. Intrigued, I decided to find out: Who is Jan Górski?

After checking the accessible databases, bibliography dictionaries and philosophy and psychology journals from the early $20^{\text {th }}$ century, it turned out that... there is no additional information on this author besides the fact that he wrote the book Świadomość jaźni and that he entered into a dispute with its reviewers.

Górski's work has the subtitle Psychological Remarks and in some library databases he himself is differentiated from other authors bearing the same name by the note "psychologist". So most likely he was a psychologist. (However, it must be noted that reactions to the book were almost solely philosophical.) Yet where did he study and work? Nobody knows. His book is based mostly on contemporary French literature, so maybe he studied in France? On the other hand, maybe our Jan Górski is the author-born in 1872-of the treatise Ein Beitrag zur Kenntnis der Aetiologie und Symptomatologio der Paralysis agitans and the book Tajemnica stygmatyczki: cztery lata bez jadła i napoju: wizyta polskiego arcybiskupa $w$ Konnersreuth? So maybe he studied in Germany? We do not know. Yet most likely our author and the author of the above texts are two different persons... Thus, we have only questions, no answers. 
I will mention later the reception of Górski's work, but I believe that I simply have not found an appropriate source that would present Górski and his place in Polish science at the turn of the $20^{\text {th }}$ century. So far, the problems I have encountered while searching for information on Górski appear to explain why I discovered his work so late...

\section{Reception?}

The reception of Górski's work is not impressive. I found three reviews of Świadomośćjaźni: a very perfunctory one by Stefan Czarnowski, ${ }^{1}$ published in Tygodnik Polski, and two more extensive ones by Stanisław Kobylecki ${ }^{2}$ (1912) and Mieczysław Jarosławski ${ }^{3}$ (1912a) published in Przeglad filozoficzny and Ruch filozoficzny respectively. Górski wrote answers both to the review by Kobylecki and to the one by Jarosławski (Górski 1912b,c), but only the latter reacts to Górski's answer (1912b).

The book was also noticed by some authors writing on body awareness (see Igel 1919; Dryjski 1922); according to Femiak (2009/2010), Leon Chwistek was interested in Górski's work, and recently he has been mentioned by Sendyka (2009).

As we can see, traces of Górski’s presence in literature are truly scarce.

\section{Chapter VI of Świadomość jaźni}

Below you will find a translation of Chapter VI (the last one) of Świadomość jaźni. Clearly, Górski's work is not free from weaknesses typical of that period. Metaphysical and epistemological findings may seem old-fashioned and dated. An unquestionable drawback is the absence of references to William James and his somatic theory of emotions (e.g. 1884; see Sendyka 2009).

Nevertheless, we present fragments of his work for two reasons: (1) his defense of the somatic approach to self or self-consciousness; (2) detailed comments on the issue of bodily awareness. Górski's work has one more merit although the translated fragment cannot testify to it. The text was to a large extent based on the literature on pathology that was at that time state of the art, especially on the works of French researchers such as Paul Sollier, Janet,

\footnotetext{
${ }^{1}$ S. Czarnowski (1879-1937) a sociologist, folklorist and historian of culture according to Sendyka (2009), a student of Durkheim.

${ }^{2}$ S. Kobylecki (1864-1939) a philosopher and Catholic priest (Jesuit); more Polish-language information about him can be found in a work by Ludwik Nowak (1967).

${ }^{3}$ M. Jarosławski (1887-1960) a Polish writer and translator, a physician by education.
} 
Dumas and many others. As it turns out, contemporary studies on self-consciousness and body awareness also show interest in the work of these researchers (Billon 2017).

We would like to draw your attention in particular to the issues of:

(a) the role of a multitude of physiological factors in self-consciousness: visceral sensations, cardioception, baroception, proprioception or general body tonus;

(b) the role that the experienced physical condition of the body plays in selfawareness;

(c) the presence of changes in the intensity of experiencing the body and its role in self-awareness; the self as a background of our experiences that constantly oscillates in intensity;

(d) minimal sense of self and ownership of experiences; ownership or mineness as a property dependent on social factors.

Although sometimes general or naive, especially in the context of contemporary knowledge, Górski’s comments are in our opinion worth recalling.

\section{Coda}

Finally, the answer to the question: Where does the eponymous year 1912 come from? As I have written, the search for traces of the scientific activity of Jan Górski did not produce much. What is surprising is not only the discovery of Górski's work but also the fact that all the texts by Górski, i.e. the book and the discussion with the review authors, come from the year 1912. Górski's research and life beyond that year remain-at least to me as I am writing these words-unknown...

\section{References}

Billon, A. (2017). Mineness First: Three Challenges to the Recent Theories of the Sense of Bodily Ownership. In de Vignemont, F. \& Alsmith, A.J.T. (eds.). The Subject's Matter: Self-Consciousness and the Body, [in print]

Czarnowski, S. (1912). Recenzja: Górski, Świadomość jaźni, Tygodnik Polski, 1, 14.

Dryjski, A. (1921). Źródła cenestezji. Przegląd Filozoficzny, 24(1-2), 34-84.

Femiak, T. (2009/2010). Pisma psychologiczne Leona Chwistka: w setną rocznicę wydania artykułu: "O zmianach periodycznych treści widzianych obrazów", Rocznik Historii Filozofii Polskiej, 23, 221-242. 
Górski J. [Johann von Gorsk] (1899). Ein Beitrag zur Kenntnis der Aetiologie und Symptomatologio der Paralysis agitans. Inaug.-Diss: Berlin.

Górski, J. (1912a). Świadomość jaźni. Uwagi psychologiczne, Gebethner-Wolff: Krakow-Warszawa.

Górski, J. (1912b). Polemika, Ruch Filozoficzny, 2(9), 189-190.

Górski, J. (1912c). Polemika (odpowiedź na krytykę pana S. Kobyleckiego), Przegląd Filozoficzny XV(4), 530-537.

Górski.J (1931). Tajemnica stygmatyczki: cztery lata bez jadła i napoju: wizyta polskiego arcybiskupa w Konnersreuth, B. Bleiweis: Łódź.

Igel S. (1919). Stosunek uczuć do przedstawień ze względu na klasyfikację faktów psychicznych. Przegląd filozoficzny, 22(4), 351-418.

Kobylecki, S. (1912). Przegląd Krytyczny. Nowa teorja tak zwanej jaźni, Przegląd Filozoficzny XV(3), 379-392.

James, W. (1884). What is an Emotion?. Mind, 9, 188-205.

Jarosławski, M. (1912a). Recenzja: Górski, Świadomość Jaźni, Ruch Filozoficzny, 2(8), 151-153.

Jaroslawski, M. (1912b) Polemika, Ruch Filozoficzny, 2(9), 190.

Nowak, L. (1967). Filozoficzno-logiczne poglądy Stanisława Kobyleckiego, Studia Philosophiae Christianae, 3(1), 111-137.

Sendyka R. (2009). O „Sobie”, eseistyce, Lambie i Brzozowskim. Przestrzenie Teorii, $12,11-44$. 